American Journal of Biochemistry and Biotechnology, 2012, 8 (2), 128-142

ISSN: 1553-3468

(C) 2012 Ghaly and MacDonald, This open access article is distributed under a Creative Commons Attribution

(CC-BY) 3.0 license

doi:10.3844/ajbbsp.2012.128.142 Published Online 8 (2) 2012 (http://www.thescipub.com/ajbb.toc)

\title{
Kinetics of Thin Layer Drying of Poultry Manure
}

\author{
A.E. Ghaly and K.N. MacDonald \\ Department of Process Engineering and Applied Science, Dalhousie University, Halifax, Canada
}

Received 2012-06-05; Revised 2012-06-14; Accepted 2012-06-18

\begin{abstract}
The poultry industry is one of the largest and fastest growing sectors of livestock production in the world. The estimated 2010 world flock was over 18 billion birds with a yearly manure output of 22 million tonnes. Storage and disposal of raw poultry manure has become an environmental problem because of the associated air, water and soil pollution. Environmental and health problems such as odor and pathogens that may arise during and after land application of raw manure can be eliminated by drying. Dried manure can be utilized as a soil conditioner to improve soil tilth and reduce the problems associated with soil compaction and as a feed for ruminants because of its high nitrogen content. The aim of this study was to investigate the kinetics of thin layer drying of poultry manure and evaluate the effects of drying with heated air on the chemical and biological properties of manure. The effects of temperature and depth of manure layer were evaluated. The profile of the moisture content of poultry manure followed an exponential decay curve. The moisture decay constant was affected by the drying temperature and the depth of the manure layer. At the three temperature levels studied, the time required to dry poultry manure in $1 \mathrm{~cm}$-deep layer was the least, followed by 2 and $3 \mathrm{~cm}$-deep layers, respectively. The diffusion coefficient increased with both temperature and depth of drying layer, but did not show a linear increase with either variable. The optimum depth for drying manure (at which the highest drying effectiveness occurred) was $3 \mathrm{~cm}$. Drying manure at $40-60^{\circ} \mathrm{C}$ resulted in the loss of $44-55 \%$ of the total Kjeldahl nitrogen, with losses increasing with both the temperature and depth of manure. The $\mathrm{pH}$ of the manure decreased from the initial value of 8.4 before drying to about 6.6 after drying. The odor analysis indicated that dried poultry manure did not have an offensive odor. Drying achieved 65.3 and $69.3 \%$ reductions in odor intensity and offensiveness, respectively. Reductions in the number of bacteria, mold/yeast and E.coli were 65-99, 74-99 and 99.97\% respectively. The greatest reductions in microbial population occurred at the highest temperatures $\left(60^{\circ} \mathrm{C}\right)$ and the thinest manure depths $(1 \mathrm{~cm})$. Heated air drying of poultry manure at temperatures between 40 and $60^{\circ} \mathrm{C}$ was effective in killing pathogens and removing odor.
\end{abstract}

Keywords: pH, Depth, Diffusion, Drying Kinetics, Plant Nutrients, Time Moisture Content, Temperature, Effectiveness, Poultry Manure

\section{INTRODUCTION}

The poultry industry is one of the largest and fastest growing sectors of livestock production in the world with a $35 \%$ increase in meat and egg production during the period of 2000-2008 (FAO, 2010). The estimated 2010 world flock was over 18 billion birds with a yearly manure output of 22 million tonnes (FAO, 2010). With the rapid expansion of the industry over the last several decades, storage and disposal of raw poultry manure has become an environmental problem because of the associated air, water and soil pollution (Benali and Kudra, 2002). Poultry manure begins to decompose immediately after excretion giving off ammonia which, in high concentrations, can have adverse effects on the health and productivity of birds as well as the health of the farm workers (Pierson et al, 2001; Zhang and Lau, 2007; Amon et al., 2006). Manure serves as a breeding ground for pathogenic microorganisms as well as a medium for diseases transmission among the birds. Flies and other undesirable insects can breed on the manure leading to the health hazards and nuisance associated with them (Lay et al., 2011; Axtell, 1999). Manure is also a source of odor caused by the activity of anaerobic microorganisms in the manure (Miller and Berry, 2005; Fares et al., 2005). It is, therefore, necessary to subject poultry manure to some treatments in order to improve its storage and handling and to 
minimize the risk of disease transmission and environmental pollution.

Environmental problems such as odor and pathogens that may arise during and after land application of raw manure can be eliminated through drying of the manure. Dried manure can be utilized as a soil conditioner to improve soil tilth and reduce the problems associated with soil compaction (Kelleher et al., 2002; Zhang and Lau, 2007; Tanabe et al., 1985; Tam and Tiquia, 1999). Poultry manure has also been the focus of feeding to ruminants because of its high nitrogen content (Alam et al., 2008). DeBoer (1981) reported that the results of a series of digestibility experiments on dried poultry manure feeding to ruminants showed an average net energy content of about $6400 \mathrm{~kJ} / \mathrm{kg}$ dried manure and an average protein content of about $300 \mathrm{~g} / \mathrm{kg}$ dried manure. The results of feeding experiments with young fattening bulls showed no effect on carcass-quality, or taste and smell of meat. Thomas et al. (1972) reported that feeding caged layer waste to dairy cattle did not affect the composition or flavour of milk.

Drying refers to the removal of moisture from the manure in order to minimize the rate of deterioration from chemical and biological activity and prevent the environmental problems associated with raw manure. Drying with heated air results in higher rates of oxidation and pathogen destruction (Loehr, 1977). Air can be heated using solar energy, electricity, natural gas or oil. However, solar energy offers many advantages over other energy sources. These include: (a) it is available in abundance all year round specifically in the tropics, (b) it is relatively cheap to collect and utilize, (c) it has a higher rate of oxidation and (d) it results in good waste stabilization, odor control and pathogen destruction (Amine-Khodja et al., 2006). El-Sayed (1993) estimated the output air temperature from a solar collector to be in the range of $25-66^{\circ} \mathrm{C}$.

The main aim of this study was to investigate the thin layer drying of poultry manure and evaluate the effects of drying with heated air on the chemical and biological properties of manure. The specific objectives were to: (a) evaluate the drying behaviour of laying hen manure at temperatures in the range of $40-60^{\circ} \mathrm{C}$ and depths of 1-3 cm, (b) determine the kinetic parameters of thin layer drying and (c) determine the changes in the chemical and biological properties of the manure as a result of the drying process.

\section{MATERIALS AND METHODS}

\subsection{Drying Trays}

Three sets of trays (each set consisting of three trays of the same dimensions) were constructed from galvanized metal sheets and used for the drying of poultry manure. Each tray had a drying surface area of $100 \mathrm{~cm}^{2}$. The depths of the trays were $1 \mathrm{~cm}, 2 \mathrm{~cm}$ and 3 $\mathrm{cm}$ for sets 1,2 and 3, respectively. Figure 1 shows the dimensions of a drying tray.

\subsection{Manure}

Poultry manure was obtained from a layers house located in Stewiack East, approximately $80 \mathrm{~km}$ from Halifax, Nova Scotia. The manure was collected under the battery cages of a laying house accommodating approximately 50,000 hens. The raw manure was not subjected to any treatment on the farm. It was placed in clean plastic bags and transported to the Waste Management Laboratory at Dalhousie University in Halifax, Nova Scotia where it was stored at $-18^{\circ} \mathrm{C}$. Some characteristics of the poultry manure used in this study are presented in Table $\mathbf{1}$.

\subsection{Experimental Procedure}

The effects of three drying temperatures (40, 50 and $60^{\circ} \mathrm{C}$ ) and three manure depths $(1-3 \mathrm{~cm})$ on the manure drying time, rate and effectiveness and manure characteristics were investigated. Prior to placing the manure in the drying trays, it was removed from the freezer and allowed to thaw for $24 \mathrm{~h}$ at room temperature $\left(22^{\circ} \mathrm{C}\right)$. The three sets of trays were weighed using a digital balance (METTLER Balance model PM4600, Fisher Scientific, Montreal, Quebec). The trays were then filled to their respective depths with the manure and weighed again. The trays and manure were then placed in a forced draft oven (Isotemp Oven Model 655F, Fisher Scientific and Montreal, Quebec) which was adjusted to the required temperature. The drying rate was monitored by determining the change in weight at $2 \mathrm{~h}$ time intervals until there was no change in weight. The oven temperature was then readjusted to the next level and the same experimental procedure was followed. Three replicas were carried out for each temperature-manure depth combination.

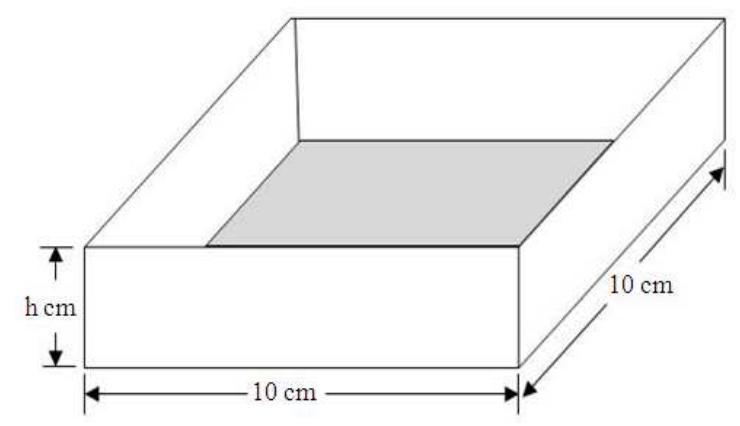

Fig. 1. Dimensions of drying trays $(\mathrm{h}=1,2$ or $3 \mathrm{~cm})$ 
Table 1. Some characteristics of the poultry manure used in the study

\begin{tabular}{lc}
\hline Item & Measured value \\
\hline Moisture content & $78.4 \%$ \\
Density & $960 \mathrm{~kg} / \mathrm{m}^{3}$ \\
Total solids & $215520 \mathrm{mg} / \mathrm{L}$ \\
Volatile solids & $139770 \mathrm{mg} / \mathrm{L}$ \\
Ash & $75750 \mathrm{mg} / \mathrm{L}$ \\
Total Chemical Oxygen Demand & $328500 \mathrm{mg} / \mathrm{L}$ \\
Soluble Chemical Oxygen Demand & $130000 \mathrm{mg} / \mathrm{L}$ \\
Total Kjedahl Nitrogen & $18960 \mathrm{mg} / \mathrm{L}$ \\
Ammonium Nitrogen & $9470 \mathrm{mg} / \mathrm{L}$ \\
Calcium & $19760 \mathrm{mg} / \mathrm{L}$ \\
Phosphorous & $5590 \mathrm{mg} / \mathrm{L}$ \\
Potassium & $4140 \mathrm{mg} / \mathrm{L}$ \\
pH & 8.40 \\
\hline
\end{tabular}

\subsection{Experimental Analyses}

The manure properties were determined before drying. These were: moisture content, density, total solids and volatile solids, ash, total and soluble chemical oxygen demand, total-Kjeldahl nitrogen, ammonium-nitrogen, $\mathrm{Ca}, \mathrm{P}$ and $\mathrm{K}$ contents, $\mathrm{pH}$, total microbial counts, pathogens, insect and odor analysis. The moisture content, density, $\mathrm{pH}$, total and volatile solids, total and soluble COD, Ca, P, K, total- Kjeldahl nitrogen, ammonium- nitrogen, total microbial count, pathogens, insects and odor analyses, were performed on the dried samples. The $\mathrm{pH}$, density, solids, chemical oxygen demand analyses were performed in the biotechnology laboratory of Dalhousie University, Halifax, Nova Scotia according to the procedures described in the Standard Methods for examination of water and waste water (APHA, 1981). The moisture content, $\mathrm{Ca}, \mathrm{P}, \mathrm{K}$, total Kjeldahl nitrogen and ammonium nitrogen analyses, microbial and insect analyses and odor tests were performed as follows.

\subsubsection{Moisture Content}

The moisture content was determined using the oven drying method according to the procedure described in the ASABE Standards (ASABE, 2008). Samples of approximately $10 \mathrm{~g}$ were dried at $103^{\circ} \mathrm{C}$ for $24 \mathrm{~h}$ in a drying oven (Isotemp Oven Model 655F, Fisher Scientific, Montreal, Quebec) and the Moisture Content (MC) was calculated as follows Equation 1:

$$
\text { MC }(\% \mathrm{wb})=\frac{(\text { Wieght of wet samples }- \text { Weight of dry sample }) \times 100}{\text { Wieght of wet samples }}
$$

\subsubsection{Elemental Analysis}

The $\mathrm{Ca}, \mathrm{P}$ and $\mathrm{K}$ analyses were performed in the Mineral Engineering Centre of Dalhousie University, Halifax, Nova Scotia. The phosphorous content was determined by the colorimetric method using a molybdivandate solution after leaching the samples with perchloric acid $\left(\mathrm{HClO}_{4}\right)$, hydrofluoric acid (HF) and nitric acid $\left(\mathrm{HNO}_{3}\right)$. The Potassium and calcium contents were determined by atomic absorption after leaching samples with $\mathrm{HNO}_{3}$ and hydrochloric acid $(\mathrm{HCl})$. These analyses were carried out according to the procedures described in the Official Methods of Analysis of the Association of Official Analytical Chemists (AOAC, 2006). Both the Total Kjeldahl Nitrogen (TKN) and ammonium nitrogen $\left(\mathrm{NH}_{4}-\mathrm{N}\right)$ contents were determined using a Kjeltech Auto Analyzer (Model 1030, Part No. 1000 1773, Serial No. 2000, Tecator AB, Hoganas, Sweden). A one gram sample of the manure was diluted with $20 \mathrm{ml}$ of distilled water for $\mathrm{NH}_{4}-\mathrm{N}$ analysis. For the TKN analysis, one gram of the manure was digested with $4 \mathrm{~mL}$ of concentrated sulfuric acid $\left(\mathrm{H}_{2} \mathrm{SO}_{4}\right)$ for $25 \mathrm{~min}$ under a vacuumed ventilator. The analyte was then automatically titrated by the analyzer.

\subsubsection{Total Microbial Count}

The number of viable aerobic and facultative microorganisms was established based on the assumption that each viable cell would develop into a colony during incubation. Manure samples were collected in wide mouth sterilized containers. Each sample was diluted to insure that one of the final plates would have $30-300$ colonies (the number of colonies within this range gives the most accurate approximation of the microbial population). The initial dilution (1:10) was prepared by placing $1 \mathrm{~g}$ of manure into $10 \mathrm{~mL}$ of physiological saline water. The bottle was then shaken vigorously to obtain a uniform distribution of organisms. Further dilutions $\left(1: 10^{3}, 1: 10^{4}, 1: 10^{5}, 1: 10^{7}, 1: 10^{8}\right)$ were made by pipetting measured aliquots into additional dilution waters. Sterile petri dishes were first labeled (specimen and dilution), then each bottle was thoroughly shaken and $1 \mathrm{~mL}$ of the appropriate dilution was pipetted into each petri dish. Approximately $15 \mathrm{~mL}$ of cooled melted medium was poured into each petri dish. Immediately thereafter, the plates were gently rotated 6 times in each direction to distribute the inoculum throughout the medium. The plates were allowed to solidify and were incubated in the inverted position in an incubator (Model Number 2020, VWR International, Cornelius, Oregon) at $35-37^{\circ} \mathrm{C}$ for 48 h. Three replicates from each dilution were carried out. Plates that contained a number of colonies in the range of 30-300 were selected. An accurate count of the colonies was made by placing the plate on the platform of a colony counter (Cat.No.7-910, Fisher Scientific, Montreal, Quebec). This instrument facilitated the counting process since the colonies were illuminated and seen against a ruled background. The number of colonies counted on each plate was multiplied by the dilution of the specimen which the plate represents. This gave the number of colonies per milliliter. 


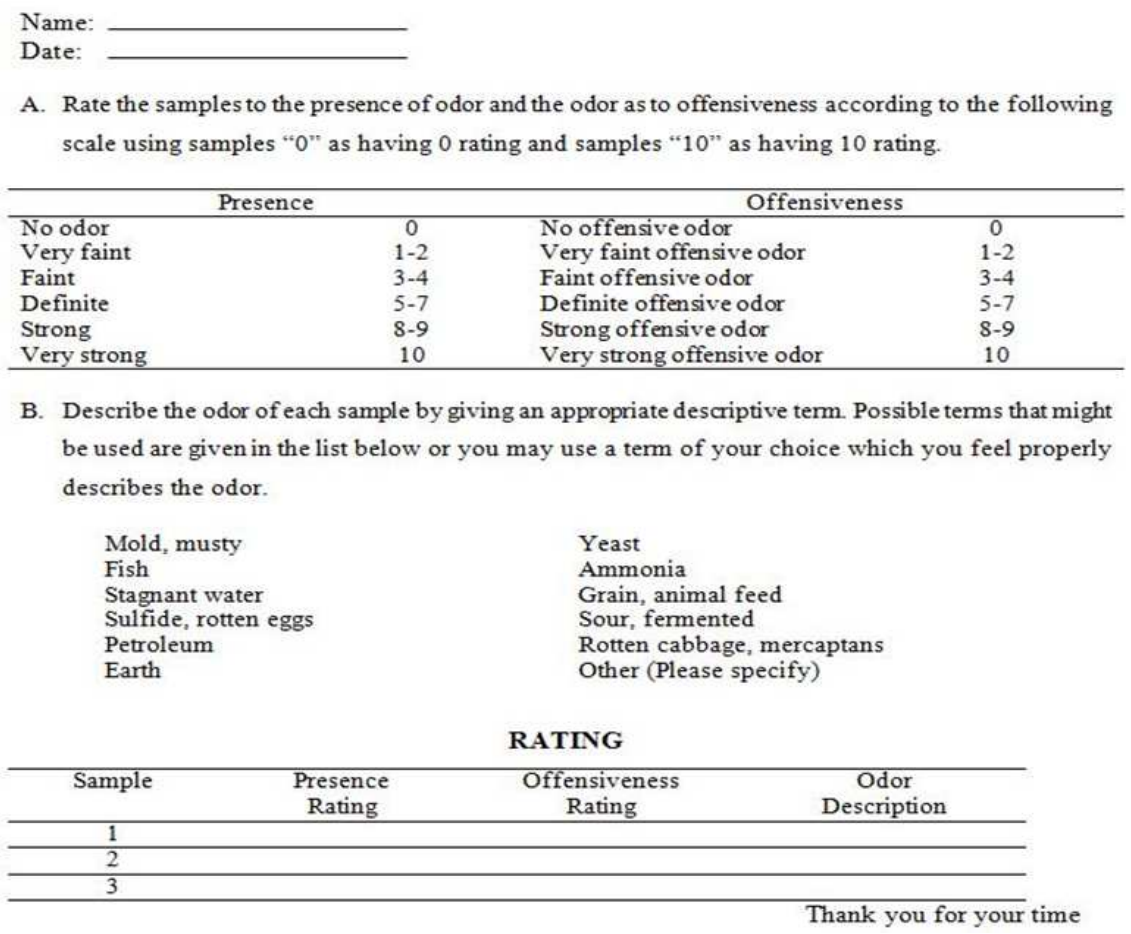

Fig. 2. Odor evaluation sheet

\subsubsection{Microbial and Insect Analyses}

The following analyses were also performed on raw dried manure samples: (a) yeast and mold enumeration, (b) E. Coli estimation, (c) Salmonellae examination and (d) microscopic examination of insect, flies eggs and parasite. These analyses were performed at Phillips Analyticals, Dartmouth, Nova Scotia.

\subsubsection{Odor}

A specially developed organoleptic test for the measurement of odor from animal waste was used to measure the presence and offensiveness of odor in poultry manure. This method was chosen because of the complex nature of manure odor which is best judged by the human nose. Scales of 0-10 were utilized to rate the odor as to its presence and offensiveness. No odor was 0 and very strong odor was 10 . Similarly, no offensive odor was 0 and very offensive odor was 10 . The intermediate numbers 1-9 are described in the score sheet (Fig. 2), which was used by the panel members to rate the samples $(50 \mathrm{~g})$ placed before them in 125 black erlenmeyer flasks. Panel members were asked to rate the contents of the flasks according to the scales of $0-10$ and to describe the odor on a separate data sheet. The lower limit (0) was assigned to distilled water, whereas the upper limit (10) was assigned to fresh poultry manure. The odor testing panel (30 members) consisted of technicians, graduate and undergraduate students and faculty.

\section{RESULTS AND DISCUSSION}

\subsection{Moisture Content Profile}

The profiles of the moisture contents of poultry manure as affected by the drying temperature and manure depth are shown in Fig. 3. The moisture contents followed an exponential decay curve which can be described by the following Equation 2:

$\mathrm{MC}_{\mathrm{t}}=\mathrm{MC}_{\mathrm{i}} \mathrm{e}-{ }^{\mathrm{kt}}$

where:

$\mathrm{MC}_{\mathrm{t}}=$ Moisture content at time $\mathrm{t}(\% \mathrm{wb})$

$\mathrm{MC}_{\mathrm{i}}=$ Initial moisture content $(\% \mathrm{wb})$

$\mathrm{T}=$ Time (h)

$\mathrm{k} \quad=$ Moisture decay rate $(\mathrm{h}-1)$

Equations 3 to 11 describe changes in moisture content at various temperatures and manure depths and are presented in Table 2. Since the initial moisture 
content of all manure samples were the same $(78.45 \%$ wet basis), variations in drying process as a result of temperature and manure depth can be determined by the moisture decay constants $(\mathrm{K})$ as shown in Fig. 4. The results indicated that the manure depth and temperature affected the diffusion and evaporation processes, the higher the temperature and the thinner the manure layer, the greater the moisture decay rate.

Drying curves exhibiting an exponential decay in moisture content were also reported for drying of potato, carrot, pepper, garlic, mushroom, onion, leek, pea, corn, celery and pumpkin (Krokida et al., 2003), tomato (Hawlader et al., 1991; Brooks et al., 2008) and hemispherical solids (Bon et al., 1997). Panchariya et al. (2002) observed that the thin layer drying kinetics for black tea was best represented by an exponential decay. Srinivasa (2007) found the exponential decay model to be the best fit to the thin layer drying of parboiled paddy. Several authors also showed accelerated drying processes with increased temperature during the drying process (Krokida et al., 2003; Bon et al., 1997; Okos et al., 1992).

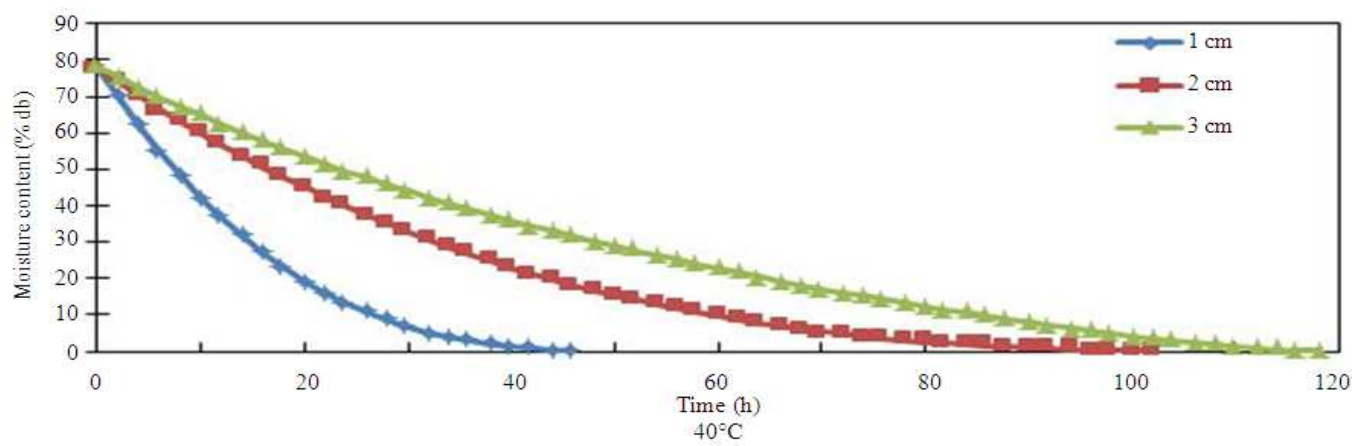

(a)

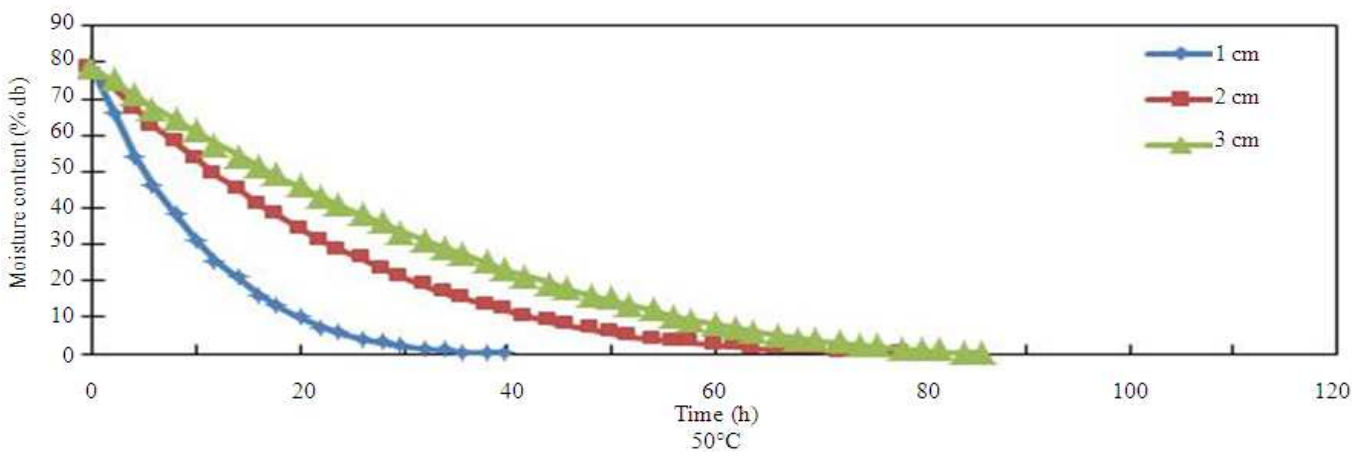

(b)

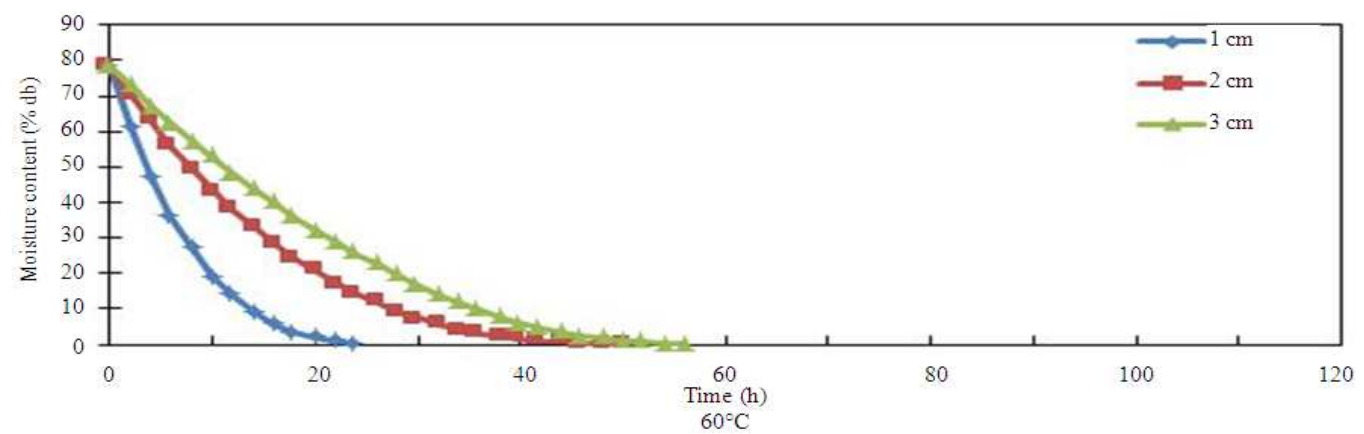

(c)

Fig. 3. Effect of drying temperature and manure depth on moisture content 
Table 2. Equations describing the moisture content at various depths and temperatures

\begin{tabular}{|c|c|c|c|c|}
\hline Drying Temperature $\left({ }^{\circ} \mathrm{C}\right)$ & Drying Depth $(\mathrm{cm})$ & Equation & $\mathrm{R}^{2}$ & Equation Number \\
\hline \multirow[t]{3}{*}{40} & 1 & $\mathrm{MC}=78.45 \mathrm{e}^{-0.000 \mathrm{r}}$ & 0.84 & 3 \\
\hline & 2 & $M C=78.45 \mathrm{e}^{-0.090 \mathrm{t}}$ & 0.73 & 4 \\
\hline & 3 & $M C=78.45 \mathrm{e}^{-0.189 t}$ & 0.83 & 5 \\
\hline \multirow[t]{3}{*}{50} & 1 & $\mathrm{MC}=78.45 \mathrm{e}^{-0.258 \mathrm{t}}$ & 0.86 & 6 \\
\hline & 2 & $\mathrm{MC}=78.45 \mathrm{e}^{-0.124 \mathrm{t}}$ & 0.86 & 7 \\
\hline & 3 & $\mathrm{MC}=78.45 \mathrm{e}^{-0.091 \mathrm{t}}$ & 0.79 & 8 \\
\hline \multirow[t]{3}{*}{60} & 1 & $M C=78.45 \mathrm{e}^{-0.351 \mathrm{t}}$ & 0.84 & 9 \\
\hline & 2 & $\mathrm{MC}=78.45 \mathrm{e}^{-0.192 \mathrm{t}}$ & 0.85 & 10 \\
\hline & 3 & $\mathrm{MC}=78.45 \mathrm{e}^{-0.144 \mathrm{t}}$ & 0.80 & 11 \\
\hline
\end{tabular}

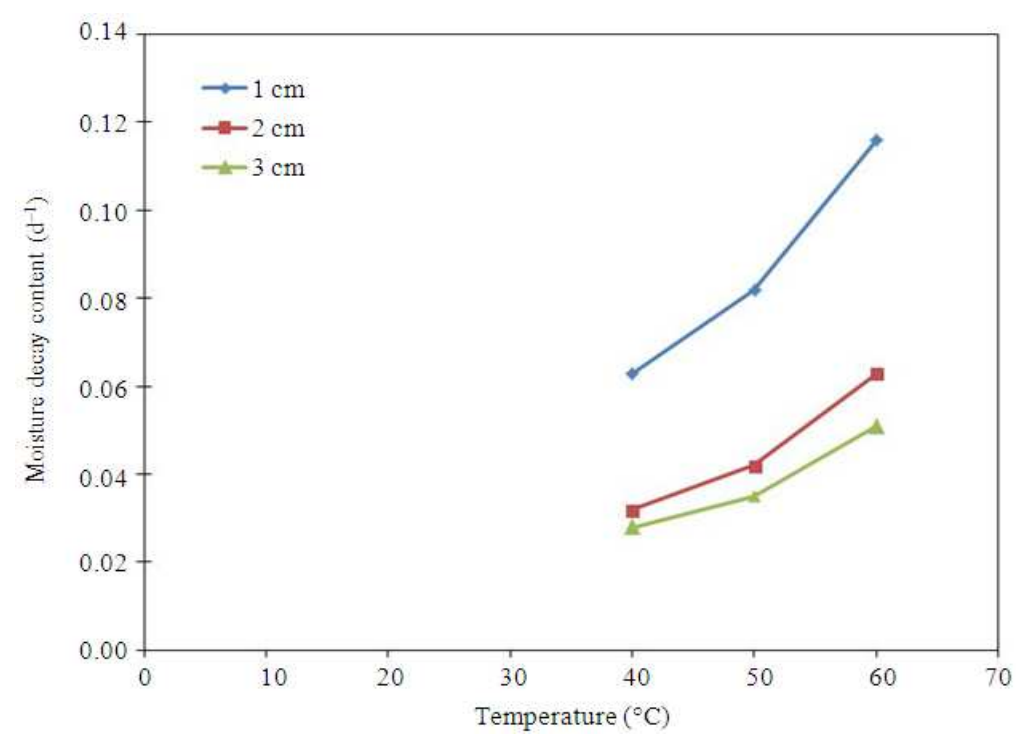

Fig. 4. Effect of temperature and manure depth on the moisture decay constant

Table 3. Drying time and drying effectiveness of poultry manure

\begin{tabular}{|c|c|c|c|c|c|c|}
\hline \multirow{2}{*}{$\begin{array}{l}\text { Drying } \\
\text { Temperature }\left({ }^{\circ} \mathrm{C}\right)\end{array}$} & \multirow{2}{*}{$\begin{array}{l}\text { Drying Depth } \\
(\mathrm{cm})\end{array}$} & \multirow{2}{*}{$\begin{array}{l}\text { Drying Time } \\
\text { (h) }\end{array}$} & \multicolumn{2}{|c|}{$\begin{array}{l}\text { Manure Weight } \\
\text { (g) }\end{array}$} & \multirow{2}{*}{$\begin{array}{l}\text { Removed Moisture } \\
(\mathrm{g})\end{array}$} & \multirow{2}{*}{$\begin{array}{l}\text { Drying Effectiveness } \\
(\mathrm{h} / \mathrm{g})\end{array}$} \\
\hline & & & Initial & Final & & \\
\hline \multirow[t]{3}{*}{40} & 1 & 55 & 125.95 & 27.15 & 98.80 & 0.56 \\
\hline & 2 & 106 & 224.70 & 48.43 & 176.27 & 0.60 \\
\hline & 3 & 120 & 312.72 & 67.41 & 245.31 & 0.50 \\
\hline \multirow[t]{3}{*}{50} & 1 & 44 & 129.16 & 27.84 & 101.32 & 0.43 \\
\hline & 2 & 84 & 226.21 & 48.71 & 177.50 & 0.47 \\
\hline & 3 & 90 & 314.28 & 67.74 & 246.54 & 0.37 \\
\hline \multirow[t]{3}{*}{60} & 1 & 28 & 127.18 & 27.41 & 99.77 & 0.28 \\
\hline & 2 & 52 & 227.86 & 49.11 & 178.75 & 0.29 \\
\hline & 3 & 60 & 322.57 & 69.52 & 253.05 & 0.24 \\
\hline
\end{tabular}

\subsection{Drying Time and Effectiveness}

The data on the drying time, removed moisture and drying effectiveness at various manure depths and drying temperatures is presented in Table 3. The parameter "drying effectiveness" is defined in this study as the time needed to drive off $1 \mathrm{~g}$ of moisture from the manure.

The results indicated that the $1 \mathrm{~cm}$ deep manure layer dried the fastest at all three drying temperatures, followed by the $2 \mathrm{~cm}$ deep manure layer and the $3 \mathrm{~cm}$ deep manure layer. The thinner the manure layer, the lower the amount of moisture it contained and consequently the shorter the time duration required to drive off the moisture. The time required to dry the $2 \mathrm{~cm}$ deep manure layer was more than the time required to dry the $1 \mathrm{~cm}$ deep manure layer by about 106, 100 and $87 \%$ for the 40,50 and $60^{\circ} \mathrm{C}$ temperatures respectively. The time required to dry the 3 $\mathrm{cm}$ deep manure layer was more than the time required to 
dry the $2 \mathrm{~cm}$ deep manure layer by 22,12 and $7 \%$ for the 40,50 and $60^{\circ} \mathrm{C}$ temperatures respectively. This shows that the difference in drying time between the shallower and deeper manure layers decrease as the temperature increases. However, the drying effectiveness of the $3 \mathrm{~cm}$ manure depth was superior at all levels of temperature as less time was required to remove one gram of water from the manure. The results also showed that more time was required to remove one gram of water from manure at the $2 \mathrm{~cm}$ depth than those required at the 1 and $3 \mathrm{~cm}$ depths at all temperatures studied, as shown in Fig. 5.

Several researchers investigated the effect of depth on the drying time and effectiveness of various materials. Rao et al. (2007) investigated the effectiveness of thin layer drying of parboiled paddy at depths between 5 and $20 \mathrm{~cm}$ and observed the fastest drying time at a depth of $5 \mathrm{~cm}$ and the optimum effectiveness at a depth in the range of $7-10 \mathrm{~cm}$. Nazghelichi et al. (2010) investigated the effect of bed depth (30,60 and $90 \mathrm{~mm}$ ) on the drying of carrot cubes and found the optimum drying time and efficiency to be achieved at the $30 \mathrm{~mm}$ depth. Maskan et al. (2002) investigated the effects of layer thickness $(0.71-2.86 \mathrm{~mm})$ at various temperatures and air velocities on the drying of fruit leather and found the optimum depth to be $0.71 \mathrm{~mm}$. Ertekin and Yaldiz (2004) investigated the effects of eggplant slice thickness $(0.63,1.27,2.54 \mathrm{~cm})$ on the drying effectiveness and reported the fastest drying times with the $0.63 \mathrm{~cm}$ thick slices and the most effective drying with the $2.54 \mathrm{~cm}$ slices.

The effect of drying temperature on the rate of drying was also investigated by several researchers. Leonard et al. (2005) investigated the effect of temperature $\left(120,140\right.$ and $160^{\circ} \mathrm{C}$ on the rate of drying of municipal sludge and observed the fastest rate of drying at $160^{\circ} \mathrm{C}$. Panchariya et al. (2002) studied thin layer drying of black tea at various temperatures $\left(80-120^{\circ} \mathrm{C}\right)$ and air velocities and found that the highest temperature resulted in the greatest drying rate. Gely and Santalla (2007) studied the effects of initial moisture content and temperature $\left(50-90^{\circ} \mathrm{C}\right)$ on the drying rate of quinoa seeds and observed the highest drying rates at $90^{\circ} \mathrm{C}$. Brook et al. (2008) investigated the effects of temperature $\left(55\right.$ and $\left.65^{\circ} \mathrm{C}\right)$ on the drying effectiveness of tomato pieces of various geometries (whole, halves, quarters and eights) and found the fastest drying rate at $65^{\circ} \mathrm{C}$ for all geometries.

\subsection{Drying Rate}

The rate of moisture removal from the poultry manure at the various depths of manure and drying temperatures was calculated as follows:

$M_{R}=\frac{W_{i}-W_{f}}{t_{i} W_{d}}$

Where:

$\mathrm{M}_{\mathrm{R}}=$ Moisture removal rate (g moisture/g dry solid/h)

$\mathrm{W}_{\mathrm{d}}=$ Weight of dry manure at the end of the drying process $(\mathrm{g})$

$\mathrm{t}_{\mathrm{i}}=$ Drying time interval $(2 \mathrm{~h})$

$\mathrm{W}_{\mathrm{i}}=$ Weight of manure at the start of a $2 \mathrm{~h}$ drying period $(\mathrm{g})$

$\mathrm{W}_{\mathrm{f}}=$ Weight of manure at the end of a $2 \mathrm{~h}$ drying period (g)

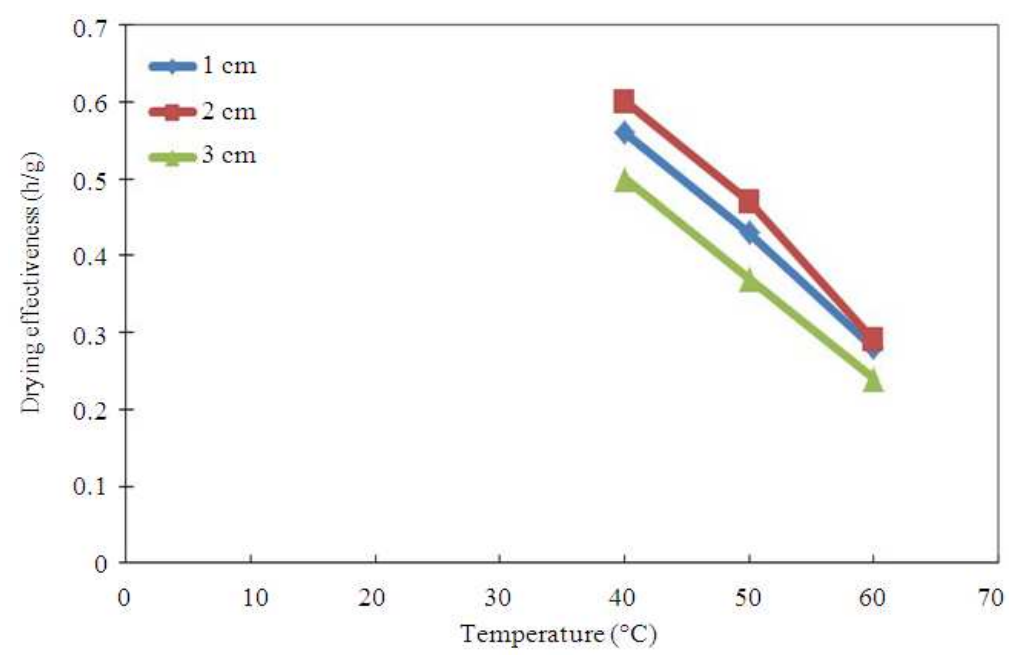

Fig. 5. Manure drying effectiveness 


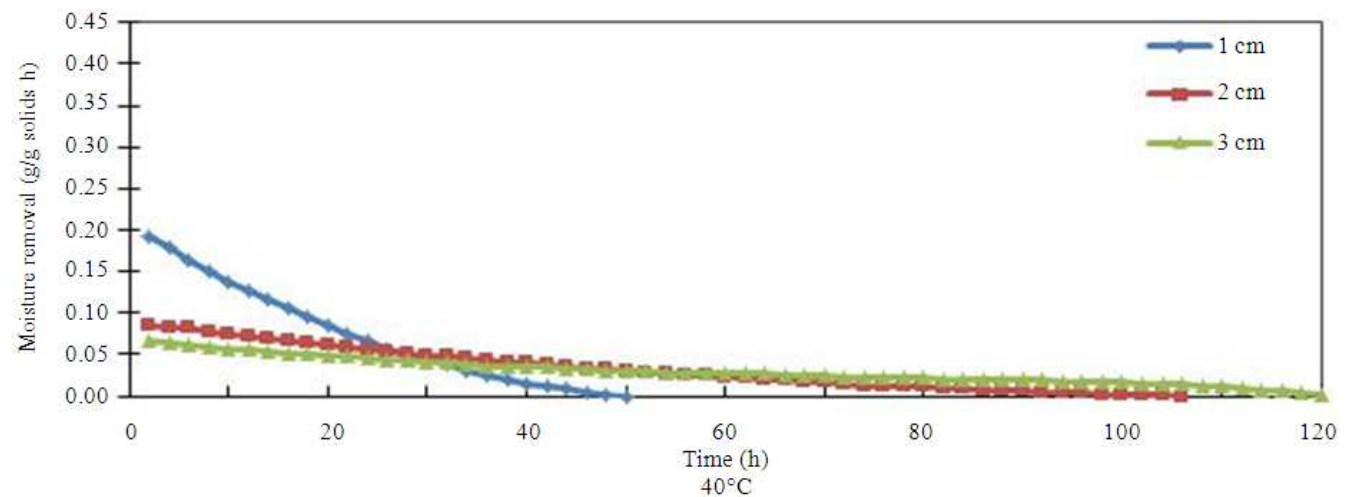

(a)

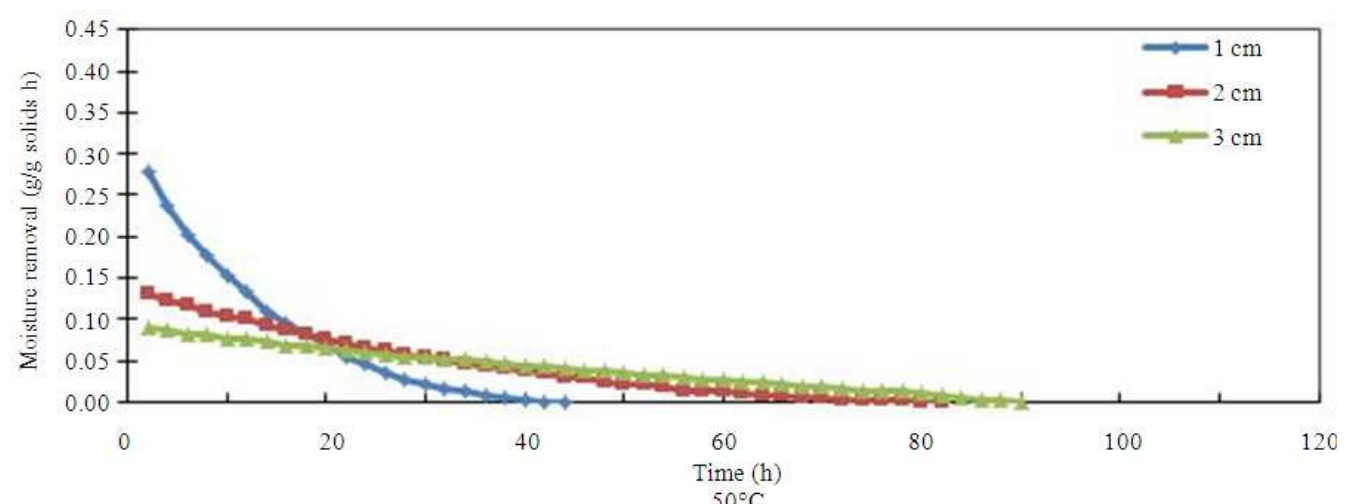

(b)

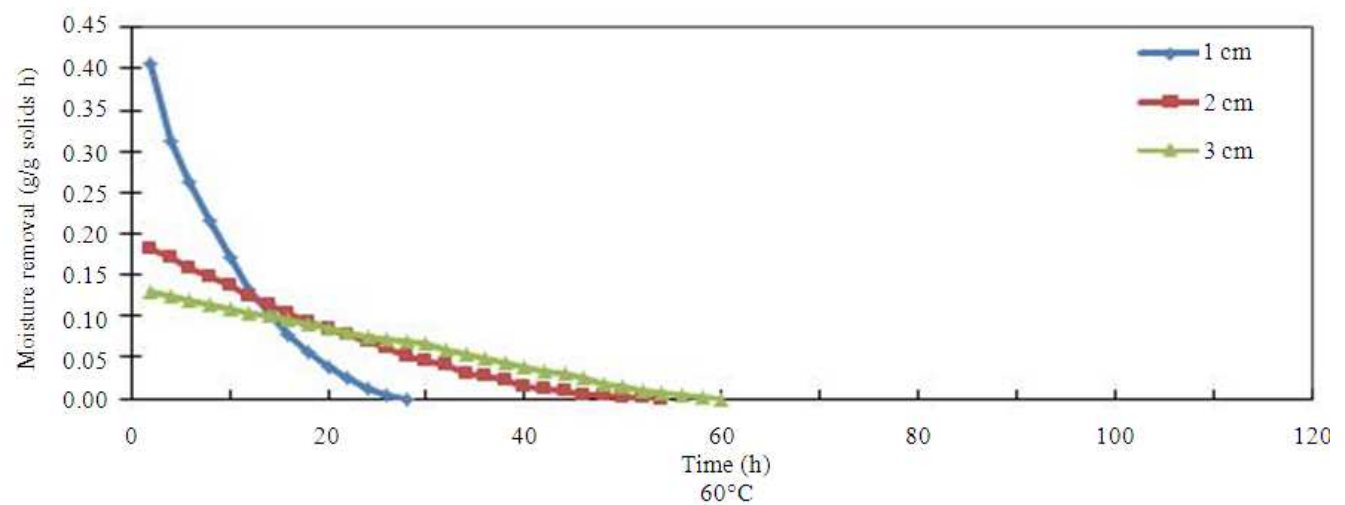

(c)

Fig. 6. Manure drying rate at various depths and temperatures

The plots of moisture removal rates as functions of time for the three manure depths and the three drying temperatures are shown in Fig. 6. The results showed that the initial drying rates were affected by both the temperature and the manure depth and the rates continued to be affected by both parameters as the drying progressed. Maskan et al. (2002) obtained similar results with the drying of grape leather at various depths $(0.71-2.86 \mathrm{~mm})$ and temperatures $\left(55-75^{\circ} \mathrm{C}\right)$ and observed that the thinnest samples and highest temperatures resulted in sustained higher drying rates. Table 4 shows the regression Equation 13 to 21 that could be used to predict the rate of moisture loss as a function of time for a given temperature-manure depth combination. 
Table 4. Equations for predicting the rate of moisture loss as a function of time

\begin{tabular}{lllll}
\hline Temperature $\left({ }^{\circ} \mathrm{C}\right)$ & Depth $(\mathrm{cm})$ & Equation & $\mathrm{R}^{2}$ & Equation \\
\hline 40 & 1 & $\mathrm{M}_{\mathrm{R}}=0.1270-0.004370 \mathrm{t}+0.000037 \mathrm{t}^{2}$ & 1.00 & 13 \\
& 2 & $\mathrm{M}_{\mathrm{R}}=0.0610-0.000962 \mathrm{t}+0.000004 \mathrm{t}^{2}$ & 1.00 & 14 \\
50 & 3 & $\mathrm{M}_{\mathrm{R}}=0.0475-0.000949 \mathrm{t}+0.000011 \mathrm{t}^{2}$ & 0.99 & 15 \\
& 1 & $\mathrm{M}_{\mathrm{R}}=0.1670-0.008090 \mathrm{t}+0.000099 \mathrm{t}^{2}$ & 0.99 & 16 \\
60 & 2 & $\mathrm{M}_{\mathrm{R}}=0.0821-0.001940 \mathrm{t}+0.000012 \mathrm{t}^{2}$ & 1.00 & 17 \\
& 3 & $\mathrm{M}_{\mathrm{R}}=0.0528-0.000588 \mathrm{t}+0.000002 \mathrm{t}^{2}$ & 0.99 & 18 \\
& 1 & $\mathrm{M}_{\mathrm{R}}=0.2530-0.017400 \mathrm{t}+0.000301 \mathrm{t}^{2}$ & 0.99 & 19 \\
& 2 & $\mathrm{M}_{\mathrm{R}}=0.1240-0.004130 \mathrm{t}+0.000034 \mathrm{t}^{2}$ & 1.00 & 20 \\
\hline
\end{tabular}

* MR $=$ Moisture removal rate $(\mathrm{g} / \mathrm{g}$ solids $\mathrm{h}) ; * \mathrm{t}=$ Time from the commencement of drying $+2(\mathrm{~h})$

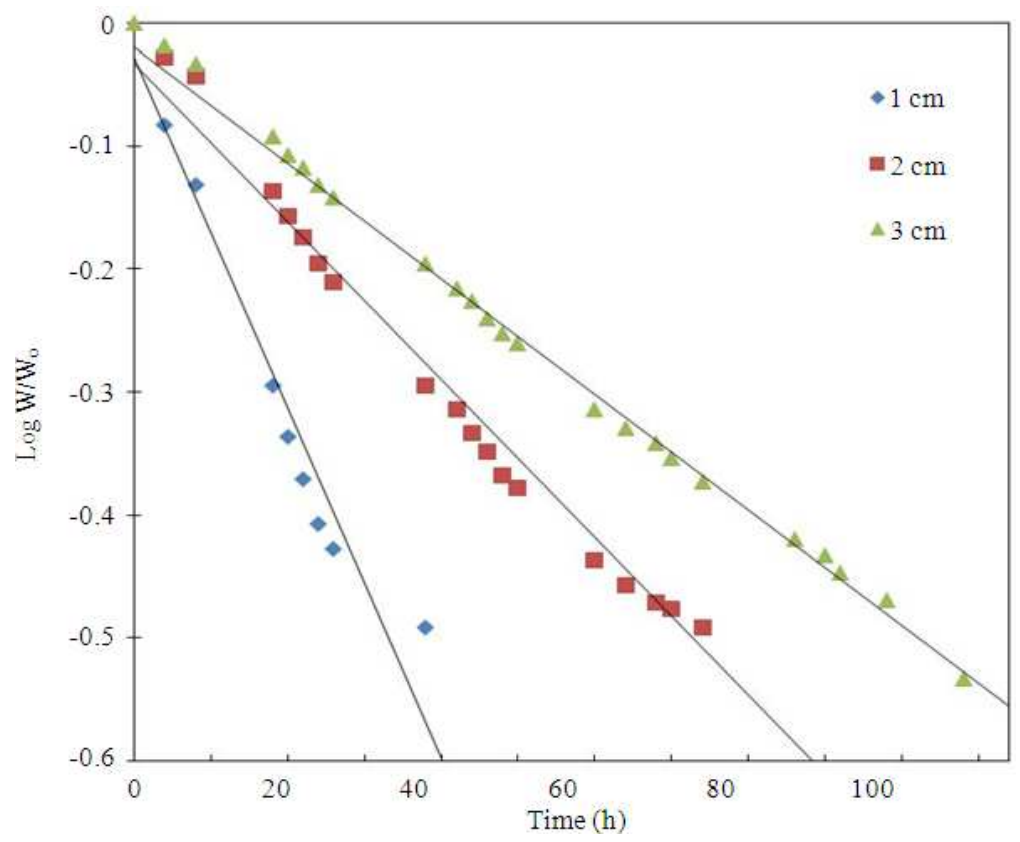

Fig. 7. Example of a logarithm plot of the moisture content verus time (at drying temperature of $40^{\circ} \mathrm{C}$ )

These equations were combined into the following regression equation that could be used to predict the moisture loss as a function of temperature, manure depth and time $\left(\mathrm{R}^{2}=0.81\right)$ :

$\mathrm{M}_{\mathrm{R}}=0.007220+0.032330 \mathrm{~T}-0.012307 \mathrm{x}-0.000917 \mathrm{t}$

$+0.000543 \mathrm{Tx}-0.000045 \mathrm{Tt}+0.000623 \mathrm{xt}$

$-0.000029 \mathrm{~T} 2-0.008497 \times 2+0.000006 \mathrm{t} 2$

Where:

$\mathrm{T}=$ Temperature $^{\circ} \mathrm{C}$ )

$\mathrm{X}=$ Manure layer depth $(\mathrm{cm})$

\subsection{Apparent Diffusion Coefficient}

The logarithmic model of moisture decay curves of manure drying indicated that the drying process is controlled entirely by liquid water diffusion. The experimental results can, therefore, be interpreted using Fick's diffusion model:

$$
\frac{\delta \mathrm{W}}{\delta \mathrm{t}}=\mathrm{D} \frac{\delta^{2} \mathrm{~W}}{\mathrm{dx}^{2}}
$$

Where:

$\mathrm{D}=$ Apparent diffusion coefficient $\left(\mathrm{cm}^{2} / \mathrm{s}\right)$

$\mathrm{W}=$ Manure weight $(\mathrm{g})$

Yusheng and Poulsen (1988) showed that in cases where drying is controlled by internal mass transfer resistance, an apparent Diffusion coefficient (D) may be obtained from the slope of plot of the logarithm of the moisture content versus time. By plotting the logarithm of the ratio of the manure's weight at time $t$ to the initial 
weight of the manure at time 0 versus time (Fig. 7), the apparent diffusion coefficients were determined at all drying conditions (Table 5).

The results showed that the temperature and the manure depth had pronounced effects on the drying rate and hence on the diffusion coefficient. However the diffusivity did not vary linearly with temperature or manure depth (Fig. 8). In other words, each degree rise in temperature did not lead to an equal increase in diffusivity. With the $1 \mathrm{~cm}$ manure thickness, the diffusion coefficient at $40^{\circ} \mathrm{C}$ was about 84 and $66 \%$ of the diffusion coefficient at 50 and $60^{\circ} \mathrm{C}$ respectively. With the $2 \mathrm{~cm}$ manure thickness, the diffusion coefficient at $40^{\circ} \mathrm{C}$ was about 84 and $47 \%$ of diffusion coefficient at 50 and $60^{\circ} \mathrm{C}$ respectively. With the manure thickness of $3 \mathrm{~cm}$, the diffusion coefficient at $40^{\circ} \mathrm{C}$ was about 72 and $43 \%$ of diffusion coefficient at 50 and $60^{\circ} \mathrm{C}$ respectively. It can also be shown using the diffusivity analysis that at $40^{\circ} \mathrm{C}$, the diffusion coefficient of the 1 $\mathrm{cm}$ drying depth is about $205 \%$ of the diffusion coefficient of the $2 \mathrm{~cm}$ depth and about $285 \%$ of the diffusion coefficient of the $3 \mathrm{~cm}$ depth. At $50^{\circ} \mathrm{C}$, the diffusion coefficient of the $1 \mathrm{~cm}$ thickness is about $205 \%$ of the diffusion coefficient of the $2 \mathrm{~cm}$ depth and about $244 \%$ of the diffusion coefficient of the $3 \mathrm{~cm}$ depth. At $60^{\circ} \mathrm{C}$, the diffusion coefficient of the $1 \mathrm{~cm}$ depth is about $146 \%$ of the diffusion coefficient of the $2 \mathrm{~cm}$ depth and $186 \%$ of the diffusion coefficient of the $3 \mathrm{~cm}$ depth.

A regression Equation was therefore used to describe the variations in the diffusion coefficients with respect to temperature and manure depth as follows:

$\mathrm{D}=0.003302+0.00327 \mathrm{~T}-0.00445 \times$

The experimental and predicted diffusion coefficients (Table 5), were plotted in Fig. 9 and the results showed a very good correlation $\left(\mathrm{R}^{2}=0.95\right)$. Also, the diffusion coefficients were plotted against the moisture decay constants as shown in Fig. 10 and the results showed a very good fit $\left(R^{2}=0.95\right)$.

Table 5. Apparent diffusion coefficients

\begin{tabular}{llll}
\hline Drying Depth $(\mathrm{cm})$ & Drying Temperature $\left({ }^{\circ} \mathrm{C}\right)$ & Experimental D $\left(\mathrm{cm}^{2} / \mathrm{h}\right)$ & Predicted D $\left(\mathrm{cm}^{2} / \mathrm{h}\right)$ \\
\hline 1 & 40 & 0.0130 & 0.0119 \\
& 50 & 0.0155 & 0.0152 \\
2 & 60 & 0.0196 & 0.0185 \\
& 40 & 0.0064 & 0.0075 \\
& 50 & 0.0076 & 0.0108 \\
3 & 60 & 0.0134 & 0.0140 \\
& 40 & 0.0046 & 0.0030 \\
& 50 & 0.0063 & 0.0063 \\
\end{tabular}

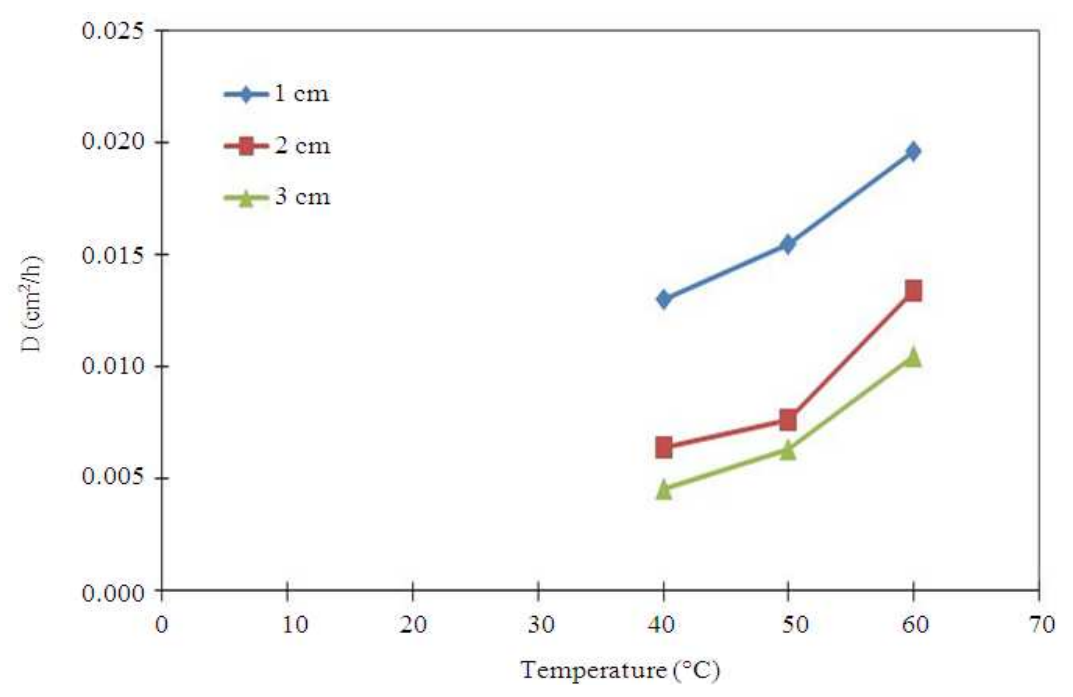

Fig. 8. Experimental diffusion coefficients (D) 


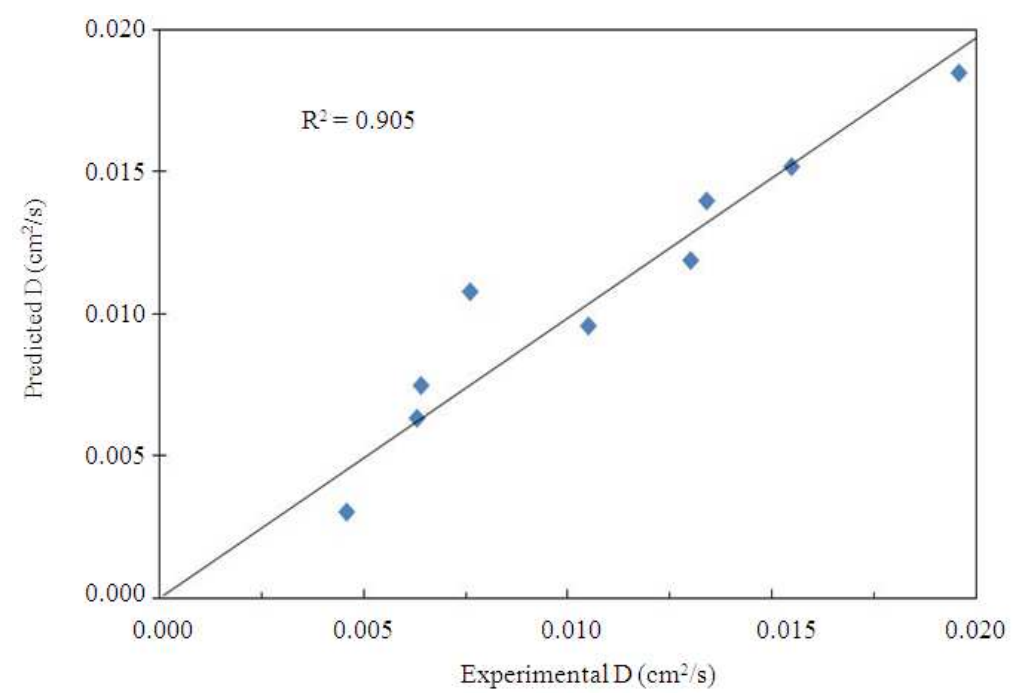

Fig. 9. Experimental and predicted apparent diffusion coefficients

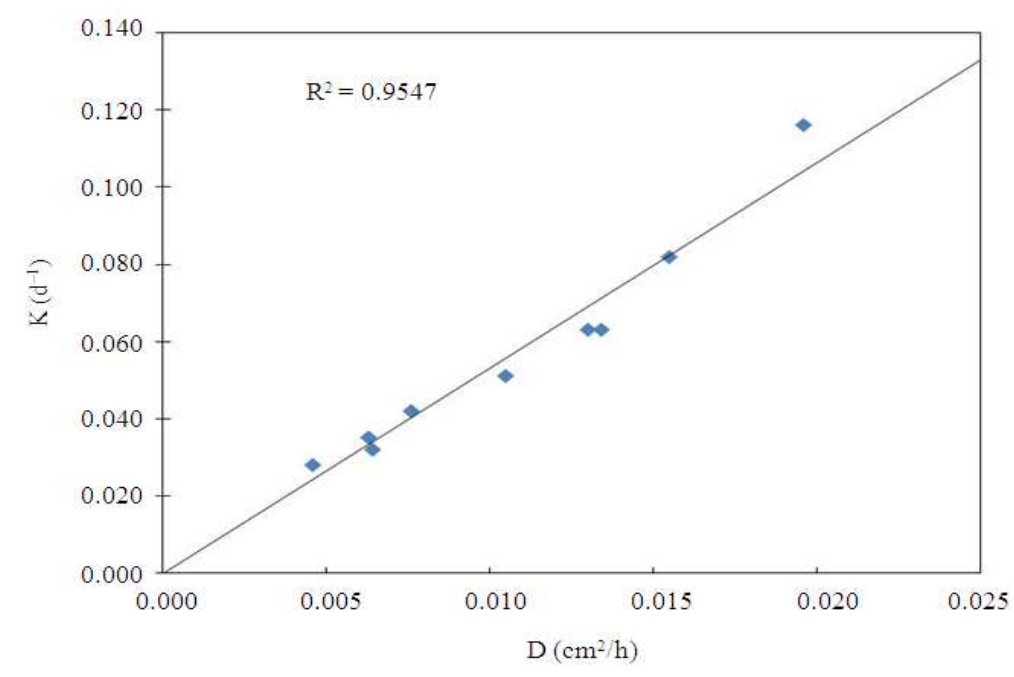

Fig. 10. Diffusion coefficients (D), vs moisture decay constants (k)

\subsection{Microbial Count}

The results of the microbial analyses are shown in Table 6. High numbers of bacteria $\left(477 \times 10^{7}\right.$ cells $/ \mathrm{g}$ manure) and yeast and mold cells (2700 cells/g manure) were found in the raw manure. The initial number of $E$. coli in the raw manure was also high $(21,986,666$ cells/g manure). The drying process reduced the number of bacteria by $65.62-99.83 \%$ (from $477 \times 10^{7}-164 \times 10^{7}$ $-808 \times 10^{4}$ cells/g manure), the yeast and mold cells by $74.07-99.63 \%$ (from 2700 cells/g manure to $700-<10$ cells/g manure) and the E. coli by $99.97 \%$ (from 21,986, $666-6263-<10$ cells/g manure). Salmonellae were detected in the raw manure and the dried manure samples of the $3 \mathrm{~cm}$ deep layer after drying at $40^{\circ} \mathrm{C}$. The results indicated that the higher the drying temperature and the thinner the manure layer, the greater the destruction of microorganisms in the dried manure.

The metabolic activities of organisms are the result of biochemical reactions, which are influenced by temperature and consequently the growth and survival of organisms are also influenced by temperature. The killing action of heat is time-temperature dependent. Practical procedures by which heat is employed are divided into two categories: (a) moist heat and (b) dry heat. However, there is a considerable difference in 
the killing efficiency of moist and dry heat on organisms. Moist heat destroys microorganisms through the denaturation of the cellular proteins and the presence of moisture facilitates this process. Dry heat dehydrates the cells and destroys microorganisms through the oxidation of their intracellular constituents. Hence, dry heat (hot air) sterilization is recommended when it is either undesirable or unlikely that steam under pressure will make direct and complete contact with the material to be sterilized.

Kim et al. (2012) studied the thermal inactivation of broiler litter by dry heat at 70,75 and $80^{\circ} \mathrm{C}$. The time required for a $7 \mathrm{log}$ reduction in Samnonellae was reported to be 80,78 and $44 \mathrm{~min}$ for the 70,75 and $80^{\circ} \mathrm{C}$ drying conditions respectively. The moisture content affected the survival of Salmonellae in the litter. When the initial moisture content of the broiler litter was increased from 30 to $50 \%$, the time required to achieve a $7 \log$ reduction was 100, 93 and 63 min for the 70,75 and $80^{\circ} \mathrm{C}$ drying temperatures, respectively Watcharasukarn et al. (2009) evaluated the efficiency of pathogen removal by dry heat at 37,55 and $70^{\circ} \mathrm{C}$ in dairy cow manure. E. coli was found to be the most heat susceptible of the 3 organisms tested (E. coli, E. fecali, C.perfringes) and sterilization times (defines as a $10 \mathrm{log}$ reduction) were found to be $5 \mathrm{~d}, 40 \mathrm{~min}$ and $10 \mathrm{~s}$ at the 37 , 55 and $70^{\circ} \mathrm{C}$ respectively. Chang et al. (1974) reported that aerobic and anaerobic microbial counts were directly related to the moisture content of dehydrated cage layer manure samples and an inverse relationship between dehydration temperature and microbial count was apparent. Aerobic and anaerobic microbial counts were significantly reduced when the moisture contents of the samples were reduced to less than $10 \%$.

\subsection{Manure $\mathbf{p H}$}

The manure $\mathrm{pH}$ dropped from 8.4 to about 6.9 as shown in Table 7. The drying temperature and drying depth did not seem to have significant effects on the $\mathrm{pH}$ of the dried manure.

\subsection{Chemical Analyses}

The concentrations of nitrogen, $\mathrm{Ca}, \mathrm{P}$ and $\mathrm{K}$ in the dried poultry manure are shown in Table 7 . Very small changes in the concentrations of $\mathrm{Ca}, \mathrm{P}$ and $\mathrm{K}$ occurred during the drying process. However, $44-55 \%$ of the nitrogen in the manure was lost depending on the depth of the manure layer and the drying temperature, the deeper the manure layer and/or the higher the temperature the greater the nitrogen loss. On average, $51 \%$ of total Kjeldahl nitrogen (13\% organic nitrogen and $38 \%$ ammonium nitrogen) in the manure was lost during the drying process. The results showed that the total protein concentration in dried manure was slightly lower than that in raw manure. Neither the drying temperature nore the depth of the manure layer appeared to have any significant effect on the final protein content of the dried manure.

Table 6. Average microbial count in raw and dried poultry manure

\begin{tabular}{|c|c|c|c|c|c|}
\hline $\begin{array}{l}\text { Drying } \\
\text { temperature }\left({ }^{\circ} \mathrm{C}\right)\end{array}$ & $\begin{array}{l}\text { Drying } \\
\text { depth }(\mathrm{cm})\end{array}$ & $\begin{array}{l}\text { Bacteria } \\
\left(10^{4} \text { cells } / g\right)\end{array}$ & $\begin{array}{l}\text { Yeast/Mold } \\
\text { (cells/g) }\end{array}$ & $\begin{array}{l}\text { E. Coli } \\
\left(10^{4} \text { cells } / g\right)\end{array}$ & $\begin{array}{l}\text { Salmonellae } \\
\text { (preserve) }\end{array}$ \\
\hline \multirow[t]{3}{*}{40} & 1 & 55000 & 250 & 10 & $\mathrm{ND}^{\mathrm{a}}$ \\
\hline & 2 & 69000 & 370 & 20 & $\mathrm{ND}^{\mathrm{a}}$ \\
\hline & 3 & 75000 & 430 & 30 & $\mathrm{PP}^{\mathrm{b}}$ \\
\hline \multirow{3}{*}{50} & 1 & 2100 & 170 & $<10$ & $\mathrm{ND}^{\mathrm{a}}$ \\
\hline & 2 & 2900 & 210 & 10 & $\mathrm{ND}^{\mathrm{a}}$ \\
\hline & 3 & 4100 & 310 & 20 & $\mathrm{ND}^{\mathrm{a}}$ \\
\hline \multirow[t]{3}{*}{60} & 1 & 440 & $<10$ & $<10$ & $\mathrm{ND}^{\mathrm{a}}$ \\
\hline & 2 & 530 & $<10$ & $<10$ & $\mathrm{ND}^{\mathrm{a}}$ \\
\hline & 3 & 620 & $<10$ & $<10$ & $\mathrm{ND}^{\mathrm{a}}$ \\
\hline Raw manure & & 477000 & 2700 & 2290 & $\mathrm{PP}^{\mathrm{b}}$ \\
\hline
\end{tabular}

a- Not Detected; b- Partially Detected

Table 7. Essential elements in raw and dried poultry manure.

\begin{tabular}{|c|c|c|c|c|c|c|c|c|c|}
\hline \multirow[b]{2}{*}{$\begin{array}{l}\text { Drying } \\
\text { temperature }\left({ }^{\circ} \mathrm{C}\right)\end{array}$} & \multirow[b]{2}{*}{$\begin{array}{l}\text { Drying } \\
\text { depth }(\mathrm{cm})\end{array}$} & \multirow[b]{2}{*}{$\mathrm{pH}$} & \multirow[b]{2}{*}{$\begin{array}{l}\text { Calcium } \\
(\%)\end{array}$} & \multirow[b]{2}{*}{$\begin{array}{l}\text { Phosphorous } \\
(\%)\end{array}$} & \multirow[b]{2}{*}{$\begin{array}{l}\text { Potassium } \\
(\%)\end{array}$} & \multicolumn{3}{|c|}{ Nitrogen (mg/kg) } & \multirow[b]{2}{*}{$\begin{array}{l}\text { Protein } \\
(\mathrm{mg} / \mathrm{kg})\end{array}$} \\
\hline & & & & & & TKN & Org-N & $\mathrm{NH}_{4}-\mathrm{N}$ & \\
\hline \multirow[t]{3}{*}{40} & 1 & 6.6 & 9.15 & 2.46 & 1.91 & 49350 & 36370 & 12980 & 40.66 \\
\hline & 2 & 6.4 & 9.16 & 2.45 & 1.90 & 46290 & 33450 & 12840 & 42.24 \\
\hline & $\overline{3}$ & 6.6 & 9.16 & 2.46 & 1.91 & 43810 & 32960 & 10850 & 42.39 \\
\hline \multirow[t]{3}{*}{50} & 1 & 6.7 & 9.15 & 2.45 & 1.90 & 45810 & 33920 & 11890 & 39.76 \\
\hline & 2 & 6.7 & 9.14 & 2.45 & 1.89 & 43490 & 32610 & 10880 & 41.96 \\
\hline & 3 & 6.7 & 9.14 & 2.46 & 1.90 & 41880 & 32060 & 9820 & 42.02 \\
\hline \multirow[t]{3}{*}{60} & 1 & 6.6 & 9.14 & 2.45 & 1.89 & 41180 & 32930 & 8250 & 39.48 \\
\hline & 2 & 6.5 & 9.13 & 2.44 & 1.90 & 39890 & 31600 & 8290 & 41.49 \\
\hline & 3 & 6.6 & 9.13 & 2.45 & 1.89 & 39260 & 30940 & 8320 & 41.59 \\
\hline Raw manure & & 8.4 & 9.17 & 2.48 & 1.92 & 87970 & 43940 & 17540 & 43.32 \\
\hline
\end{tabular}


Table 8. Odor rating

\begin{tabular}{lcc}
\hline Parameter & Dried & Raw \\
\hline Presence & $3.47 \pm 1.25$ & 10 \\
Offensiveness & $3.07 \pm 1.53$ & 10 \\
Description & & \\
Grain, Feed & 10 & - \\
Mold, Musty & 6 & - \\
Sour, Fermented & 4 & - \\
Yeast & 2 & - \\
Earth & 2 & - \\
Fish & 2 & - \\
Sulfide, Rotten Egg & 2 & 12 \\
Ammonia & 2 & 2 \\
Stagnant water & - & 3 \\
Rotten Cabbage Mercaptans & - & \\
\hline
\end{tabular}

a- Total number of observations- 30

\subsection{Odor}

At the start of each experiment, the odor given off near the oven during the drying process was noticeable. However, as the drying process progressed, the presence and offensiveness of the odor decreased with time and the final product (dried manure) did not have any offensive odor. The results of the organoleptic test (Table 8) showed that both the presence and offensiveness of the odor in the dried poultry manure were reduced by 65.3 and $69.3 \%$ (when compared to that of the fresh poultry manure), respectively. The odor present in the dried manure was not offensive $(23.3 \%$ of the panel members described the odor as that of grain, $20 \%$ described it as a mold musty, $13.3 \%$ described it as ammonia, $13.3 \%$ described it as sour/fermented, $6.7 \%$ described it as fish odor, $6.7 \%$ described it as yeast odor and $6.7 \%$ described it as sulfide rotten eggs odor).

\section{CONCLUSION}

The profile of the moisture content of poultry manure followed an exponential decay curve. The moisture decay constant was affected by the drying temperature and the depth of the manure layer. At the three temperature levels studied, the time required to dry poultry manure in the $1 \mathrm{~cm}$-deep layer was the least, followed by the 2 and $3 \mathrm{~cm}$-deep layers, respectively. The diffusion coefficients increased with both temperature and depth of drying layers, but did not show linear increases with either variable. The optimum depth to dry manure (at which the highest drying effectiveness occurred) was $3 \mathrm{~cm}$. Drying manure at $40-60^{\circ} \mathrm{C}$ resulted in the loss of $44-55 \%$ of the total Kjeldahl nitrogen, with losses increasing with both the temperature and depth of manure. The $\mathrm{pH}$ of the manure decreased from the initial value of 8.4 before drying to about 6.6 after drying. The odor analysis indicated that dried poultry manure did not have an offensive odor. Drying achieved 65.3and 69.3\% reductions in odor intensity and offensiveness, respectively. A significant reduction in the microbial population was achieved at all drying conditions. The greatest reductions in the microbial population occurred at the highest temperature $\left(60^{\circ} \mathrm{C}\right)$ and the lowest manure depth $(1 \mathrm{~cm})$. Reductions in the number of bacteria, mold/ yeast and E.coli were 65-99, 74-99 and 99.97\% respectively. Heated air drying of poultry manure at temperatures between 40 and $60^{\circ} \mathrm{C}$ proved effective in killing pathogens and removing odor.

\section{ACKNOWLEDGEMENT}

This research was funded by the Natural Science and Engineering Research Council (NSERC) of Canada.

\section{REFERENCES}

Alam, M.S., M.J. Khan, M.A. Akbar and M. Kamruzzaman, 2008. Broiler litter and layer manure in the diet of growing bull calves. Banglaseh Veterinarian, 25: 62-67. DOI: 10.3329/bvet.v25i2.4619

Amine-Khodja, A., C. Richard, B. Lavedrine, G. Guyot and O. Trubetskaya et al., 2006. Water-soluble fractions of composts for the photodegradation of organic pollutants in solar light. Environ. Chem. Lett., 3: 173-177. DOI: 10.1007/s10311-005-0028-8

Amon, B., V. Kryvoruchko, T. Amon and S. Zechmeister-Boltenstern, 2006. Methane, nitrous oxide and ammonia emissions during storage and after application of dairy cattle slurry and influence of slurry treatment. Agric. Ecosyst. Environ., 112: 153-162. DOI: 10.1016/j.agee.2005.08.030

AOAC, 2006. Official Methods of Analysis of AOAC International. 18th Edn., AOAC International, Gaithersburg, MD., ISBN-10: 0935584773, pp: 2400.

APHA, 1981. Standard Methods for the Examination of Water and Wastewater. 15th Edn., American Public Health Association, Washington, DC., ISBN-10: 0875530915 , pp: 1134.

ASABE, 2008. ASABE Standards. 55th Edn., American Society of Agricultural and Biological Engineers, Saint Joseph, MI., ISBN-10: 1892769670, pp: 1168. 
Axtell, R.C., 1999. Poultry integrated pest management: status and future. Integrated Pest Manage. Rev., 4: 53-73. DOI: 10.1023/A:1009637116897

Benali, M. and T. Kudra, 2002. Thermal dewatering of diluted organic suspensions: Process mechanism and drying kinetics. Dry. Technol., 20: 935-951. DOI: 10.1081/DRT-120003770

Bon, J., S. Simal, C. Rosselló and A. Mulet, 1997. Drying characteristics of hemispherical solids. J. Food Eng., 34: 109-122. DOI: 10.1016/S0260-8774(97)00098-8

Brooks, M.S., N.H. Abou El-Hana and A.E. Ghaly, 2008. Effects of tomato geometries and air temperature on the drying behavior of plum tomato. Am. J. Applied Sci., 5: 1369-1375. DOI: 10.3844/ajassp.2008.1369.1375

Chang, T.S., D. Dorn and H.C. Zindel, 1974. Stability of poultry anaphage. Poult. Sci., 5: 2221-2224. DOI: 10.3382/ps.0532221

DeBoer, A.J., 1981. Socioeconomic aspects of dairying in developing countries. J. Dairy Sci., 64: 2453-2462.

DOI: 10.3168/jds.S0022-0302(81)82870-6

El-Sayed, H.S., 1993. Solar drying of poultry manure for animal feed under simulated Egyptian conditions. Unpublished $\mathrm{PhD}$ thesis, Cairo University, Giza, Egypt.

Ertekin, C. and O. Yaldiz, 2004. Drying of eggplant and selection of a suitable thin layer drying model. J. Food Eng., 63: 349-359. DOI: 10.1016/j.jfoodeng.2003.08.007

FAO, 2010. Agricultural Handbook: Poultry Meat and Eggs. 1st Edn., FAO Investment Center Division, Rome Italy.

Fares, F., A. Albalkhi, J. Dec, M.A. Bruns and J.M. Bollag, 2005. Physicochemical characteristics of animal and municipal wastes decomposed in arid soils. J. Environ. Q., 34: 1392-1403. DOI: 10.2134/jeq2004.0257

Gely, M.C. and E.M. Santalla, 2007. Moisture diffusivity in quinoa (Chenopodium quinoa Willd.) seeds: Effect of air temperature and initial moisture content of seeds. J. Food Eng., 78: 1029-1033. DOI: 10.1016/j.jfoodeng.2005.12.015

Hawlader, M.N.A., M.S. Uddin, J.C. Ho and A.B.W. Teng, 1991. Drying characteristics of tomatoes. J. Food Eng., 14: 259-268. DOI: 10.1016/0260-8774(91)90017-M
Kelleher, B.P., J.J. Leahy, A.M. Henihan, T.F. O'Dwyer and D. Sutton et al., 2002. Advances in poultry litter disposal technology- a review. Bioresource Technol., 83: 27-36. DOI: 10.1016/S0960-8524(01)00133-X

Kim, J., J. Dia, M.W. Shepherd, R. Singh, S.D. Heringa and C. Gong et al., 2012. Validating thermal inactivation of Salmonella spp. in fresh and aged chicken litter. Applied Environ. Microbiol., 78: 1302-1307.

Krokida, M.K., V.T. Karathanos, Z.B. Maroulis and D. Marinos-Kouris, 2003. Drying kinetics of some vegetables. J. Food Eng., 59: 391-403. DOI: 10.1016/S0260-8774(02)00498-3

Lay, Jr. D.C., R.M. Fulton, P.Y. Hester, D.M. Karcher and J.B. Kjaer et al., 2011. Hen welfare in different housing systems. Poult. Sci., 90: 278-294. DOI: 10.3382/ps.2010-00962

Leonard, A., S. Blacher, P. Marchot, J.P. Pirard and M. Crine, 2005. Convective drying of wastewater sludges: Influence of air temperature, superficial velocity and humidity on the kinetics. Dry. Technol.: Int. J., 23: 1667-1679. DOI: 10.1081/DRT-200065082

Loehr, R.C., 1977. Food, Fertilizer and Agricultural Residues. 1st Edn., Ann Arbor Science Publishers Inc, Michigan, Illinois, ISBN-10: 0250401908, pp: 727.

Maskan, A., S. Kaya and M. Maskan, 2002. Hot air and sun drying of grape leather (pestil). J. Food Eng., 54: 81-88. DOI: 10.1016/S0260-8774(01)00188-1

Miller, D.N. and E.D. Berry, 2005. Cattle feedlot soil moisture and manure content. J. Environ. Q., 34: 644-655. DOI: $10.2134 /$ jeq2005.0644

Nazghelichi, T., M.H. Kianmehr and M. Aghbashlo, 2010. Thermodynamic analysis of fluidized bed drying of carrot cubes. Energy, 35: 4679-4684. DOI: 10.1016/j.energy.2010.09.036

Okos, M.R., G. Narismhan, R.K. Singh and A.C. Witnauer, 1992. Food Dehydration. In: Handbook of Food Engineering, Heldman, D.R. and D.B. Lund, (Eds.), CRC Press, Boca Raton, ISBN-10: 0824753313, pp: 1023.

Panchariya, P.C., D. Popovic and A.L. Sharma, 2002. Thin-layer modelling of black tea drying process. J. Food Eng., 52: 349-357. DOI: 10.1016/S0260-8774(01)00126-1 
Pierson, S.T., M.L. Cabrera, G.K. Evanylo, H.A. Kuykendall and C.S. Hoveland et al., 2001. Phosphorus and ammonium concentrations in surface runoff from grasslands fertilized with broiler litter. J. Environ. Q., 30: 1784-1789. DOI: 10.2134/jeq2001.3051784x

Rao, P.S., S. Bal and T.K. Goswami, 2007. Modelling and optimization of drying variables in thin layer drying of parboiled paddy. J. Food Eng., 78: 480-487. DOI: 10.1016/j.jfoodeng.2005.10.019

Srinivasa, S., 2007. Capacity limits of cognitive radio with distributed and dynamic spectral activity. IEEE J. Selected Areas Commun., 25: 529-537. DOI: 10.1109/JSAC.2007.070403

Tam, N.F.Y. and S.M. Tiquia, 1999. Nitrogen transformation during co-composting of spent pig manure, sawdust litter and sludge under forced-aerated system. Environ. Technol., 20: 259-267. DOI: 10.1080/09593332008616816

Tanabe, Y., K. Tanaka and Z. Kato, 1985. Feeding poultry waste to chickens, swine and cattle. Proceedings of the Agricultural Waste Utilization and Management, (AWUM' 85), ASAE Publication, St. Joseph, Michigan, pp: 13-85.
Thomas, J.W., Y. Yu, P. Tinnimitt and H.C. Zindel, 1972. Dehydrated poultry waste as a feed for milking cows and growing sheep. J. Dairy Sci., 55: 1261-1265. 10.3168/jds.S0022-0302(72)85659-5

DOI:

Watcharasukarn, M., P. Kaparaju, J.P. Steyer, K.A. Krogfelt and I. Angelidaki, 2009. Screening Escherichia coli, Enterococcus faecalis, and Clostridium perfringens as indicator organisms in evaluating pathogen-reducing capacity in biogas plants. Microbial. Ecol., 58: 221-230. DOI: 10.1007/s00248-009-9497-9

Yusheng, Z. and K.P. Poulsen, 1988. Diffusion in potato drying. J. Food Eng., 7: 249-262. DOI: 10.1016/0260-8774(88)90007-6

Zhang, W. and A. Lau, 2007. Reducing ammonia emission from poultry manure composting via struvite formation. J. Chem. Technol. Biotechnol., 82: 598-602. DOI: $10.1002 /$ jctb. 1701 